NOAA Technical Report NMFS Circular 409

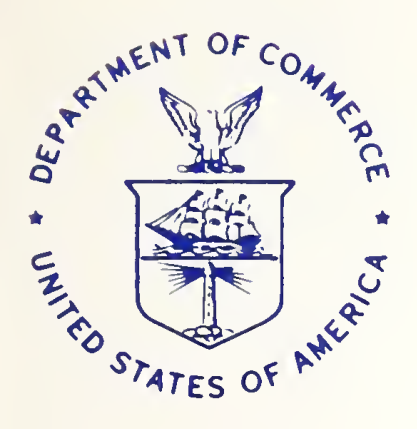

\title{
Marine Flora and Fauna of the Northeastern United States. Copepoda: Cyclopoids Parasitic on Fishes
}

\author{
Ju-Shey Ho
}

February 1978

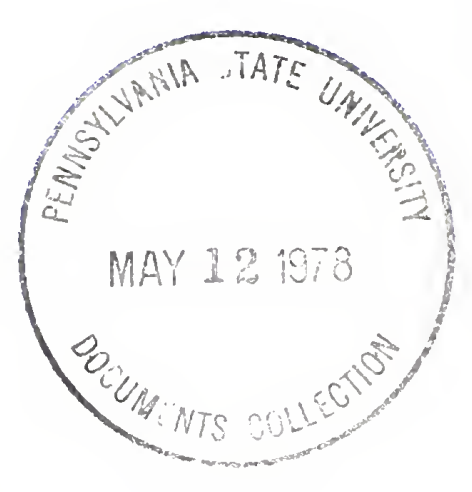

U.S. DEPARTMENT OF COMMERCE National Oceanic and Atmospheric Administration National Marine Fisheries Service 


\title{
NOAA TECHNICAL REPORTS
}

\section{National Marine Fisheries Service, Circulars}

\begin{abstract}
The majur responsibilities of the National Marine Fisheries Service (NMFS) are to monitor and assess the abundance and geographic dispributum of tishery resures. to understand and predict fluctuations in the quantity and distribution of these resources, and to establish levels tor optimum use of the resources. NMFs is also charged with the derelopment and implementation of policies for managing national fishing srounds. development and enforcement of domestic fisheries regulations, surveillance of foreign tishing off United States coastal waters, and the development and enforcement of international fishery agreements and policies. NMFS also assists the fishing industry through marketing service and economic analysis programs, and mortgage insurance and vessel construction suhsidies. It collects, analyzes, and publishes statistics on various phases of the industry.

The NOAA Technical Report NMFs Circular series continues a series that has been in existence since 1941. The Circulars are technical publications of peneral interest intended to aid conservation and management. Publications that review in considerable detail and at a high technical level certain broad areas of research appear in this series. Technical papers originating in economics studies and from management in vestigations appear in the Circular series.

VOA Technical Report NMFS Circulars are available free in limited numbers to governmental agencies, both Federal and State. They are also) available in exchange for other scientific and technical publications in the marine sciences. Individual copies may be obtained (unless wherwise noted) from D825. Technical Information Division, Environmental Seience Information Center, NOAA. Washington, D.C. 20235. Recent Circulars are:
\end{abstract}

36.5. Processing EASTROPAC STD data and the construction of ver tical temperature and salinity sections by computer. By Forrest R. Miller and Kenneth A. Bliss. February 1972, iv +17 p., 8 figs, 3 app. figs. For sale by the Superintendent of Documents. U.S. Government Printing Office. Washington. D.C. 20402

isiti. Liev to field identification of anadromous juvenile salmonids in the Pacific Xorthwest. By Robert J. MacConnell and George R. Snyder Januars 1972 iv + 6 p 4 figs. For sale by the Superintendent of Documents. U.S. Government Printing Office, Washington, D.C. 20402.

367. Engineering economic model for fish protein concentration processes, By K. K. Almenas, L. C. Durilla, R. C. Ernst, J. W. Gentry, M B. Hale and J. M. Marchello. October 1972, iii + 175 p., 6 figs., 6 tables. For sale by the Superintendent of Documents, U.S. Government Printing Office, Washington. D.C. 20402

368. Cooperative Gulf of Mexico estuarine inventory and study Florida: Phase I, area description. By J. Kneeland McNulty, William N Lindall. Jr. and James E. Sykes. November 1972, vii + 126 p., 46 figs., 62 tables. For sale by the Superintendent of Documents, U.S. Government Printing Office, Washington, D.C. 20402

369. Field guide to the anglefishes (Pomacanthidae) in the western Atlantic. By Henry A. Feddern. November 1972, iii + 10 p., 17 figs. For sale by the Superintendent of Documents, U.S. Government Printing Office. Washington, D.C. 20402

370. Collecting and processing data on fish eggs and larvae in the California Current region. By David Kramer, Mary J. Kalin, Elizabeth G. Stevens, James R. Thrailkill, and James R. Zweifel, November 1972, is +38 p., 38 figs. 2 tables. For sale by the Superintendent of Documents, U.S. Government Printing Office, Washington, D.C. 20402

371. Ocean fishery management: Discussion and research. By Adam A Sokoloski (editor). (17 papers, 24 authors.) April 1973, vi + 173 p., 38 figs.. 32 tables, 7 app. tables.

372. Fishery publications, calendar year 1971: Lists and indexes. By Thomas A. Nanar. October 1972, iv +24 p., $1 \mathrm{fcg}$. For sale by the superintendent of Documents, U.F. Government Printing Office, Washington. D.C. 20402

374 Marine flora and fauna of the northeastern United States Annelida: Oligochaeta. By David G. Cook and Ralph O. Brinkhurst. May 1973 . iii +2.3 p.. 82 figs. For sale by the Superintendent of Documents, L.S. Gusernment Printing Office, Washington, D.C. 20402.

375. Vew Polychaeta from Beaufort, with a key to all species recorded from Vorth Carolina. By John H. Day. July 1973, xiii + 140 p., 18 figs., 1 table. For sale by the Superintendent of Documents, U.S. Government Printing Office, Washington, D C, 20402.

376. Bottom-water temperatures on the continental shelf, Nova Scotia 10 Vew Jersey. Bry John B Colton. Jr. and Ruth R. Stoddard. June 1973 iii +55 p., 15 figs.. 12 app. tables. For sale by the Superintendent of Drsuments. U.S. Government Printing Office, Washington, D.C. 20402
377. Fishery publications, calendar year 1970: Lists and indexes. By Mary Ellen Engett and Lee C. Thorson. December 1972, iv + 34 p., 1 fig. For sale by the Superintendent of Documents, U.S. Government Printing Otfice, Washington. D.C. 20402

37. Narine flora and fauna of the northeastern United States. Protozna: Ciliophora. By Arthur C. Borror. September 1973, iii + 62 p., 5 ligs. For sale by the Superintendent of Documents, U.S. Government Printing Ottice, Washington, D.C. 20402

379 Fishery publications, calendar year 1969: Lists and indexes. By Lee C. Thorson and Mary Ellen Engett. April 1973, iv + 31 p., 1 fig. For sale by the Superintendent of Documents, U.S. Government Printing Office, Washington, D.C. 20402

380. Fishery publications, calendar year 1968: Lists and indexes. By Mary Ellen Fingett and Lee C. Thorson. May 1973, iv + 24 p., 1 fig. For rale by the Superintendent of Documents, U.S. Government Printing Office, Washington, D.C. 20402

381. Fishery publications, calendar year 1967: Lists and indexes. By Lee C. Thorson and Mary Ellen Engett. July 1973, iv +22 p., 1 fig. For sale by the Superintendent of Documents, U.S. Government Printing Office, Washington, D.C. 20402

382. Fishery publications, calendar year 1966: Lists and indexes. By Mary Ellen Engett and Lee C. Thorson. July 1973, iv + 19 p., 1 fig. For sale by the Superintendent of Documents, U.S. Government Printing Office, Washington, D.C. 20402

38. Fishery publications, calendar year 1965: Lists and indexes. By Lee C. Thorson and Mary Ellen Engett. July 1973, iv +12 p., 1 fig. For sale hy the Superintendent of Documents, U.S. Government Printing Office, Washington, D C, 20402

384. Marine flora and fauna of the northeastern United States. Higher plants of the marine fringe. By Edwin T. Moul. September 1973, iii +60 p., 109 tigs. For sale by the Superintendent of Documents, U.S. Government Printing Office, Washington, D.C. 20402.

385. Fishery publications, calendar year 1972: Lists and indexes. By Lee C. Thorson and Mary Ellen Engett. November 1973, iv + 23 p., 1 fig. For sale by the Superintendent of Documents, U.S. Government Printing Of fice. Washington, D.C. 20402

386. Marine flora and fauna of the northeastern United States. Pyc nogonida. By Lawrence R. McCloskey. September 1973, iii + 12 p., 1 fig. For sale by the Superintendent of Documents, U.S. Government Printing Office, Washington. D.C. 20402

387. Marine flora and fauna of the northeastern United States Crustacea: Stomatopoda. By Raymond B. Manning. February 1974, iii + 6 p., 10 tigs. For sale by the Superintendent of Documents, U.S. Government Printing Office, Washington, D.C. 20402. 
NOAA Technical Report Circular 409

Marine Flora and Fauna of the Northeastern United States. Copepoda: Cyclopoids Parasitic on Fishes

Ju-Shey Ho

February 1978

U.S. DEPARTMENT OF COMMERCE Juanita M. Kreps, Secretary

National Oceanic and Atmospheric Administration

Richard A. Frank, Administrator

National Marine Fisheries Service 


\section{FOREWORD}

This issue of the "Circulars" is part of subseries entitled "Marine Flora and Fauna of the Northeastern ['nited States." This subseries will consist of original, illustrated, modern manuals on the identification, classification, and general biology of the estuarine and coastal marine plants and animals of the Northeastern United States. Manuals will be published at irregular intervals on as many taxa of the region as there are specialists available to collaborate in their preparation.

The manuals are an outgrowth of the widely used "Keys to Marine Invertebrates of the Woods Hole Region." edited by R. I. Smith, published in 1964, and produccd under the auspieces of the SystematicsEcology Program, Marine Biological Laboratory, Woods Holc, Mass. Instead of revising the "Woods Hole Keys." the staff of the Systematics-Ecology Program decided to expand the geographic coverage and bathymetric range and produce the keys in an entirely new set of expanded publications.

The "Marine Flora and Fauna of the Northeastern United States" is being prepared in collaboration with systematic specialists in the United States and abroad. Each manual will be based primarily on recent and ongoing revisionary systematic research and a fresh examination of the plants and animals. Each major taxon, treated in a separate manual, will include an introduction, illustrated glossary, uniform originally illustrated keys, annotated check list with information when available on distribution, habitat, life history, and related biology, references to the major literature of the group, and a systematic index.

These manuals are intended for use by biology students, biologists, biological oceanographers, informed laymen, and others wishing to identify coastal organisms for this region. In many instances the manuals will serve as a guide to additional information about the species or the group.

Geographic coverage of the "Marine Flora and Fauna of the Northeastern United States" is planned to include organisms from the headwaters of estuaries seaward to approximately the 200-m depth on the continental shelf from Maine to Virginia, but may vary somewhat with each major taxon and the interests of collaborators. Whenever possible representative specimens dealt with in the manuals will be deposited in the reference collections of major museums in the region.

After a sufficient number of manuals of related taxonomic groups have been published, the manuals will be revised, grouped, and issued as special volumes. These volumes will thus consist of compilations of individual manuals within phyla such as the Cnidaria, Arthropoda, and Mollusca, or of groups of phyla. 


\section{CONTENTS}

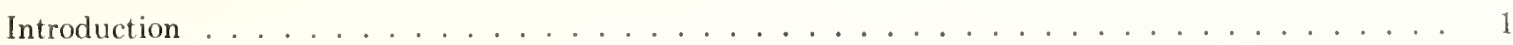

Key to the marine cyclopoid copepods parasitic on fishes of the northeastern United States . . . 2

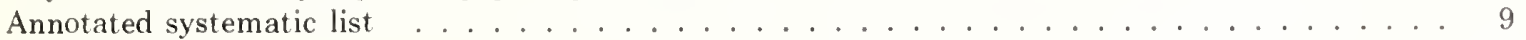

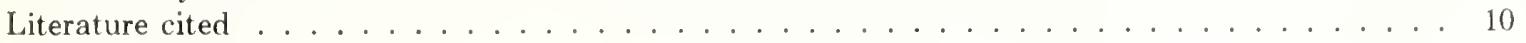

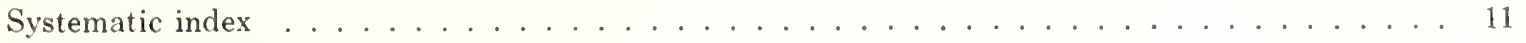

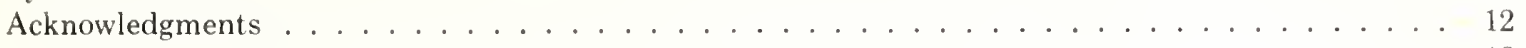

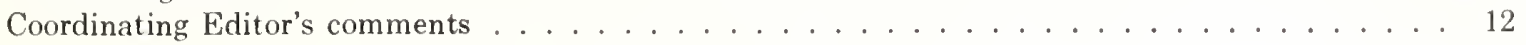

The National Marine Fisheries Service (NMFS) does not approve, recommend or endorse any proprietary product or proprietary material mentioned in this publication. No reference shall be made to NMFS, or to this publication furnished by NMFS, in any advertising or sales promotion which would indicate or imply that NMFS approves, recommends or endorses any proprietary product or proprietary material mentioned herein, or which has as its purpose an intent to cause directly or indirectly the advertised product to be used or purchased because of this NMFS publication. 



\title{
Marine Flora and Fauna of the Northeastern United States. Copepoda: Cyclopoids Parasitic on Fishes
}

\author{
JU-SHEY HO ${ }^{1}$
}

\begin{abstract}
This manual includes an introduction on the general biology, an illustrated key, an annotated systematic list, a selected bibliography, and an index to the 19 species of cyclopoid copepods parasitic on marine fishes of the northeastern United States.
\end{abstract}

\section{INTRODUCTION}

The "Order Cyclopidea" as defined by Yamaguti (1963) consists of four families of copepods parasitic on both freshwater and marine fishes. They are Bomolichidae, Ergasilidae, Grandiunguidae, and Tuccidae. However, according to Sproston et al. (1950), Ho (1967b, 1970, 1971a), Izawa (1973), and Cressey (1975), the Order should include six more families: Lernaeidae, Telsidae, Chondracanthidae, Pharodidae, Philichthyidae, and Shiinoidae; and the family Bomolichidae should be separated into the Bomolochidae and Taeniacanthidae. The family Grandiunguidae was created by Yamaguti (1963) to accommodate a single species of copepod, Grandiungus promicrops Pearse 1952. I have checked the type-specimen of this species deposited in the National Museum of Natural History in Washington, D.C., and have discovered that it is merely a chalimus larva of a lernaeocerid copepod detached from its frontal filament. Therefore, the family Grandiunguidae together with its monotypic genus and species, Grandiungus promicrops, should be discarded. Consequently, the "Order $\mathrm{Cy}$ clopidea" as it now stands consists of ten families, namely, Bomolochidae, Chondracanthidae, Ergasilidae, Lernaeidae, Pharodidae, Philichthyidae, Shiinoidae, Taeniacanthidae, Telsidae, and Tuccidae. The lernaeids are exclusively parasitic on freshwater fishes and the ergasilids are predominently parasites of freshwater fishes, except a few species that are found on fishes of brackish or coastal waters. The members of the other eight families are strictly marine parasites.

Cyclopoid copepods on fishes are found on the body surface or in the oral cavity, gill cavity, nasal cavity, and cephalic canal. They attach to the host by hooking their modified, prehensile second antennae (Ergasilidae, Chondracanthidae, Pharodidae, Tuccidae), maxillae (Telsidae), or maxillipeds (Bomolochidae, Shiinoidae, Taeniacanthidae); by burrowing their anchorlike

'Department of Biology, California State University, Long Beach, CA 90840 . modified cephalothorax (Lernaeidae); or by boring into and lying free inside the cephalic canal of the host's gill operculum and head (Philichthyidae).

Our knowledge of the biology of this group of parasites is still scanty. A complete life cycle is known of only some freshwater species. Some sporadic reports on the larval stages are available for a few marine species. However, based on the existing information, it seems that the parasitic cyclopoids do not require an intermediate host. The nauplius hatched from the egg develops into the copepodid larva, which is the infective stage and searches for the new host. Usually, there are five copepodid stages and mating takes place right after the female finishes its last molt in the larval stage. The male dies after mating, but occasionally it is found holding to the genital segment of the ovigerous female (Bomolochidae, Shiinoidae, Taeniacanthidae, Telsidae) or lying in the host's cephalic canal with the mature female (Philichthyidae). However, in the family Chondracanthidae, the male is characteristically a symbiont of the female; it is a dwarf (Fig. 1) and holds on to one of the two vermiform processes on the female trunk near the genital somite. Therefore, adult cyclopoids found attached to fishes are all female. The mature females of the families Chondracanthidae, Lernaeidae, Pharodidae, Philichthyidae, Shiinoidae, and Tuccidae are highly transformed and do not appear as a typical cyclopoid (Fig. 2). In these modified copepods an extensive but gradual modification of the body occurs in the process of maturation after the last molt in the copepodid stage.

While all the cephalic and oral appendages are retained with certain degree of modification in the adult female, the thoracic appendages of the parasitic cyclopoids exhibit a wide spectrum of variation. While the maxillipeds are lacking in some families (Ergasilidae, Philichthyidae, Shiinoidae), the remaining thoracic appendages vary from the typical unmodified cyclopoid thoracopods (Ergasilidae, Lernaeidae) through the partially (Bomolochidae, Taeniacanthidae, Telsidae, Tuccidae) or completely (Chondracanthidae, Pharodidae, Philichthyidae) modified legs to the absence of the legs entirely (Chondracanthidae, Philichthyidae). 


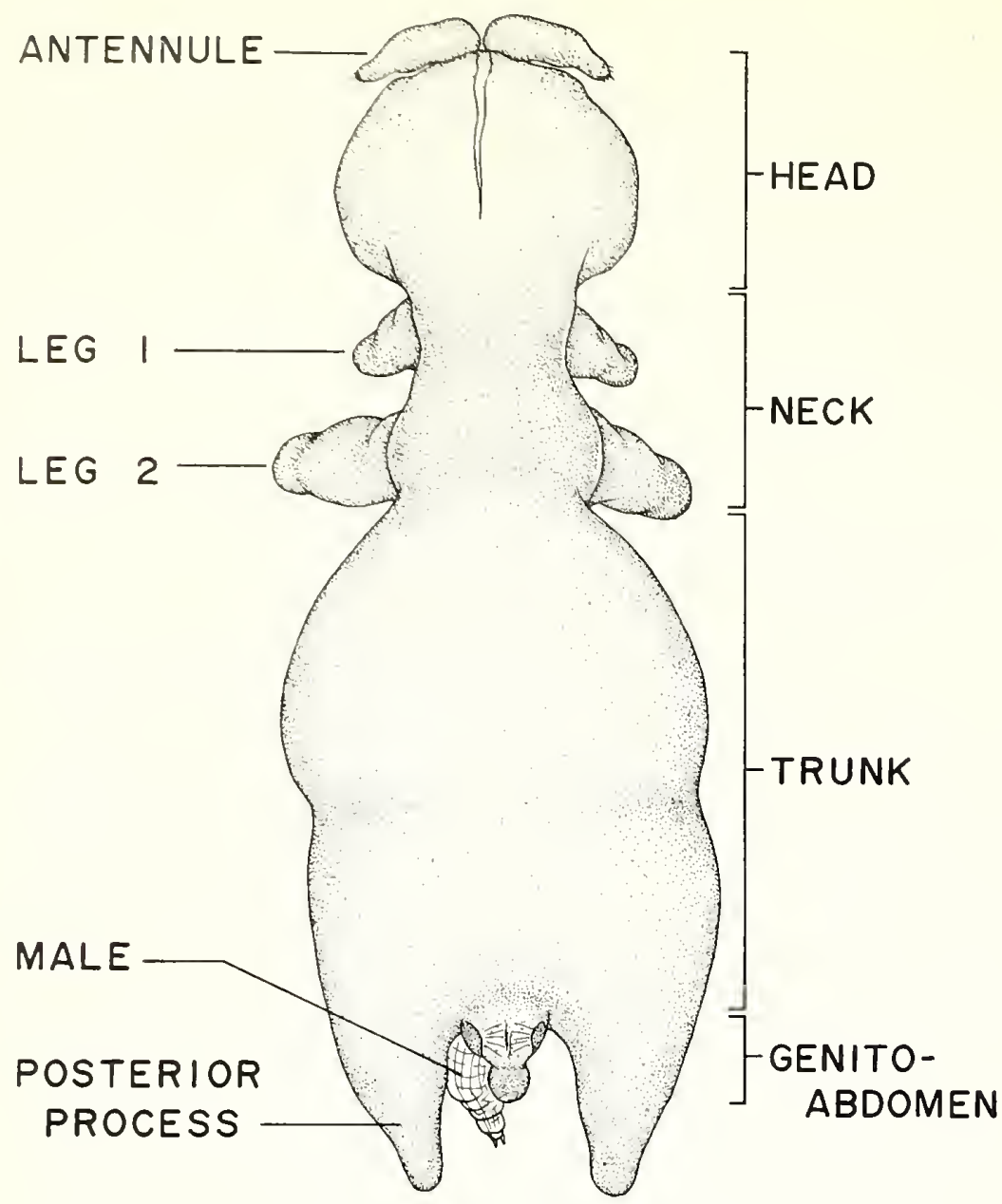

Figure 1.-Acanthochondria cornuta; dorsal view, showing structures and terms used in key.

There are about 380 species of cyclopoids parasitic on marine fishes. However, only 19 species belonging to six families are so far known to occur within the range covered by this manual (from Maine to Virginia). Since only a small fraction of fishes occurring off the coast of northeastern United States have ever been examined for the copepod parasites, certainly many more species of parasitic cyclopoids are yet to be discovered.

It is well known that a freshwater fish heavily infested with cyclopoids, particularly with those of the genera Ergasilus and Lernaea, often dies. Although no such reports have ever been made on marine fishes, a fish kill due to heavy infestation of marine cyclopoid copepods cannot be ruled out, because loss of weight and retardation of the rate of growth of the fish under the influence of parasitism is known.

In collecting specimens of parasitic cyclopoids, one must be very careful not to damage the attachment apparatus of the parasite, for, in many cases, this modified appendage carries important taxonomic information. Removal of the parasite from the host is preferably done under a dissecting microscope, but, if the removal must be done in the field, a generous amount of the host tissue must be taken together with the parasite. The parasite is subsequently removed from the collected host's tissue under a dissecting microscope in the laboratory. The collected specimens are preserved and stored in $70 \%$ alcohol. The study of their external anatomy always requires dissection of the appendages. This can be done first by soaking the specimen in lactic acid for several hours and then removing the appendages under a dissecting microscope with a pair of sharp needles. The appendages removed are studied under a compound microscope.

\section{KEY TO THE MARINE CYCLOPOID COPEPODS PARASITIC ON FISHES OF THE NORTHEASTERN UNITED STATES}

The following key is constructed for the female cycloprids that have been reported parasitic on marine fishes from Maine to Virginia. A separate key to the male is not given because some of them are unknown and the others, 


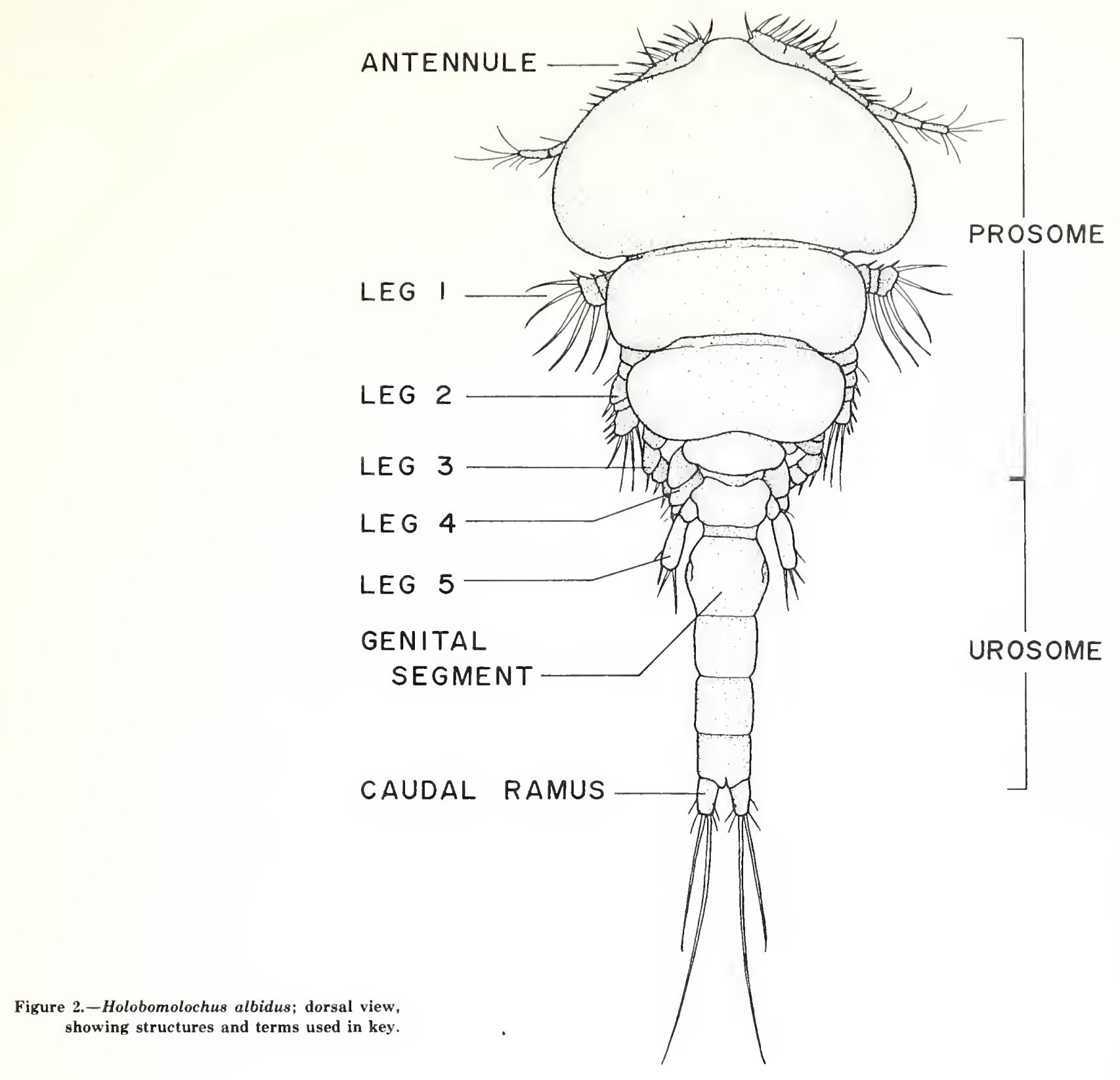

when they occur, are always in close association with their female partners.

Although 19 species of cyclopoids are known from the northeastern United States, the following key is prepared for identification of the 11 species of Chondracanthidae, one species of Philichthyidae, and one species of Tuccidae. Identification of the remaining three species of
Bomolochidae, two species of Ergasilidae, and one species of Taeniacanthidae is not provided because these families are relatively large and very poorly known from the region. If a key to the few known species is provided, it might lead a user to misidentify an unreported species as one listed in the key. 


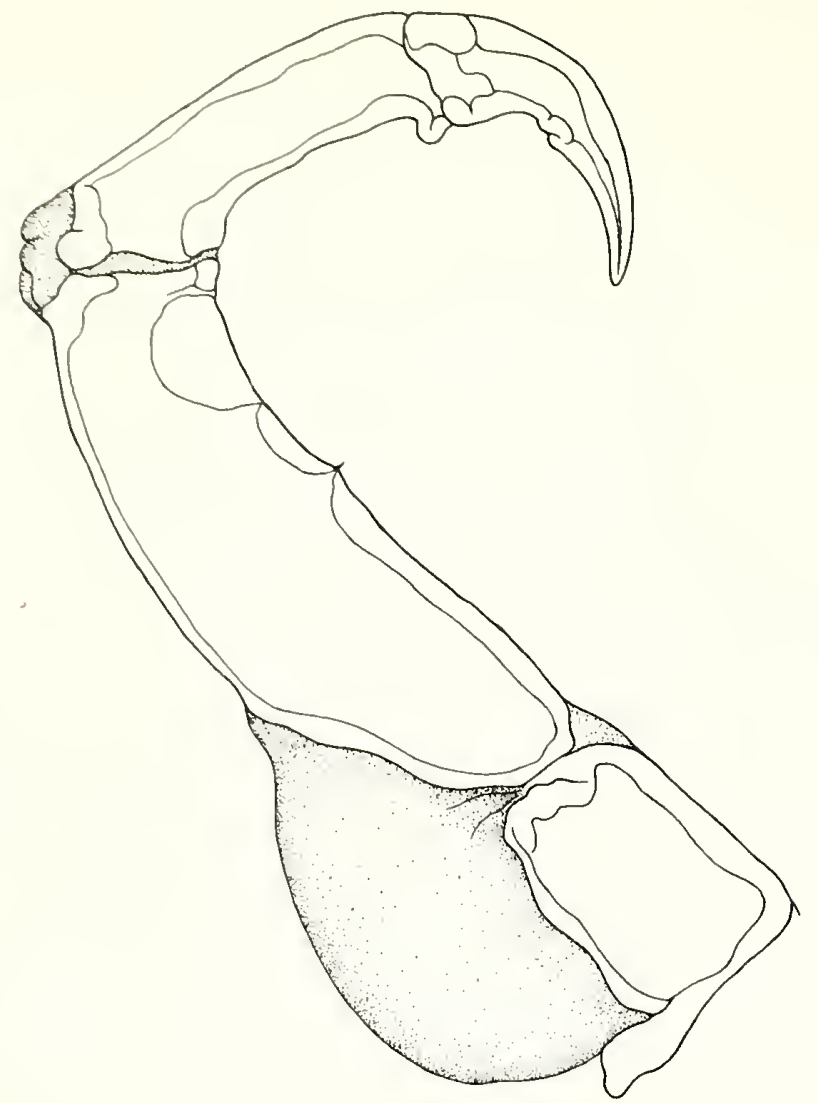

Figure 3.-Ergacilus labracis; antenna.

Figure 4.-Tucca impressus; antenna.

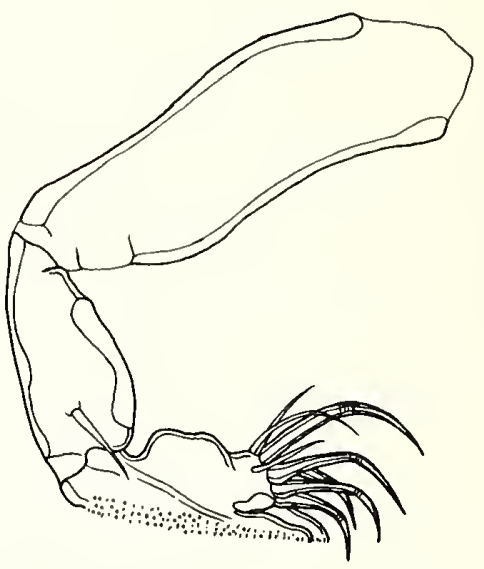

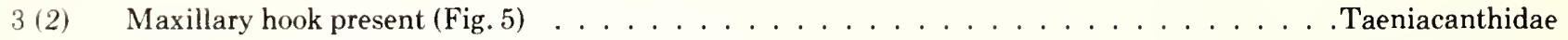

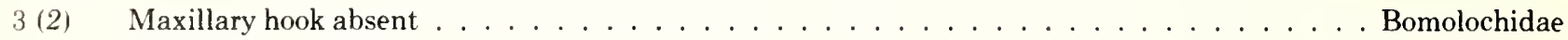

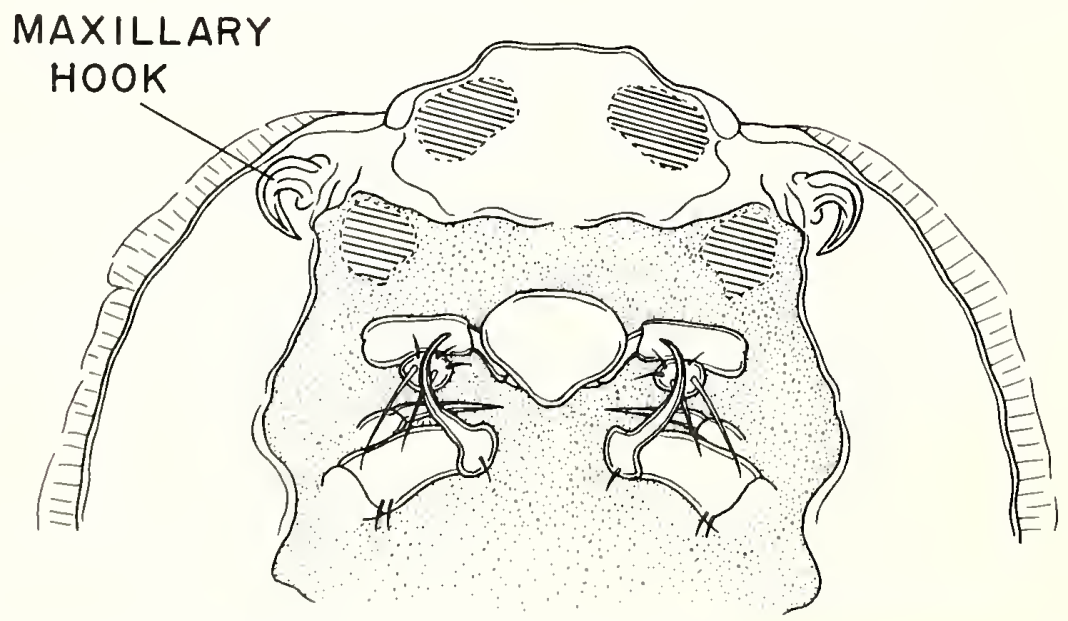

Figure 5.-Anchistrotos occidentalis; cephalothorax in ventral view with antennules and antennae removed. 
4 (1) Without attachment apparatus, living loosely in cephalic canal of fish (fig. 6) . . . . Philichthys xiphiae

Figure 6.-Philichthys xiphiae; female.

4 (1) With attachment apparatus of modified antennae or maxillipeds, firmly attached to host tissue . . . . . . . 5

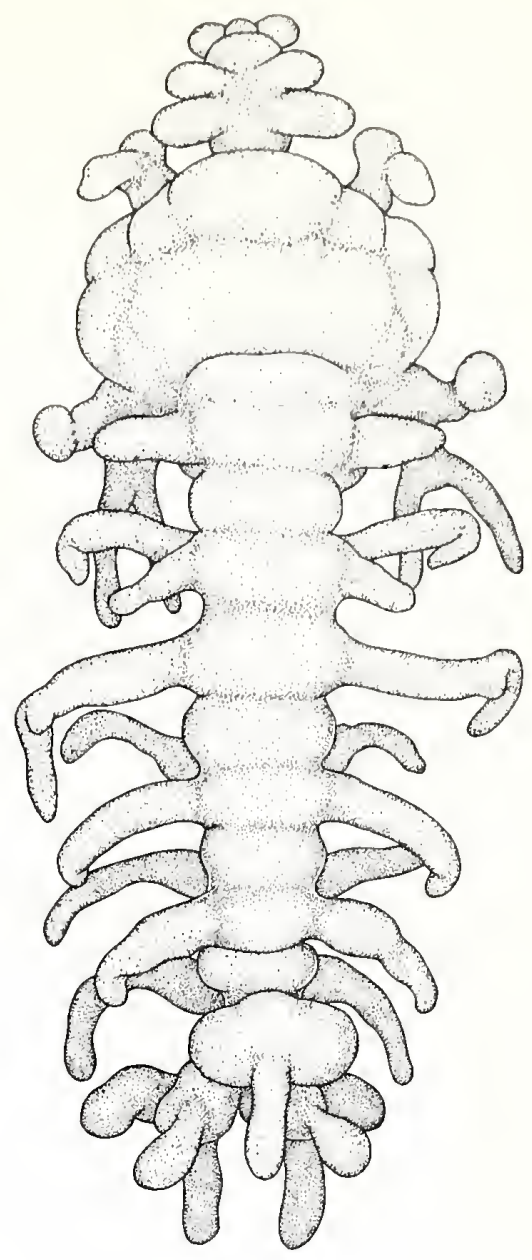

5 (7) Antenna bearing several terminal setae and claws (Fig. 4) . . . . . . . . . Tucca impressus

5 (7) Antenna transformed into a tripartite process (Fig. 7) or a recurved hook (Fig. 8) $\ldots \ldots \ldots$

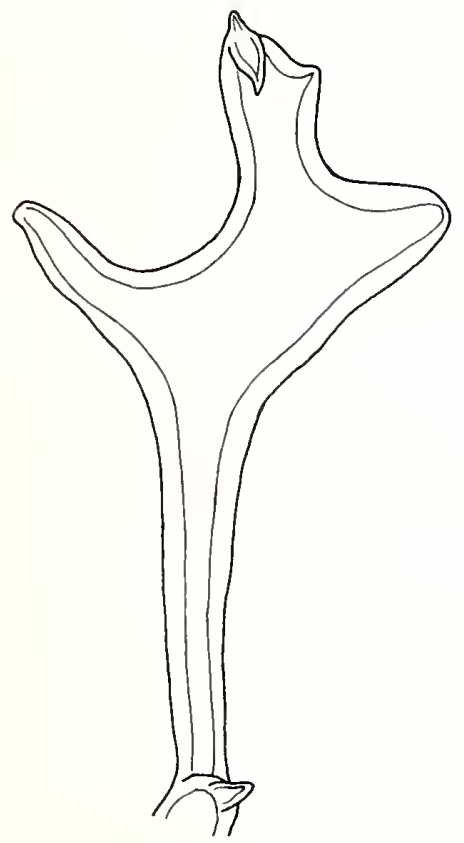

Figure 7.-Blias prionotus; antenna.

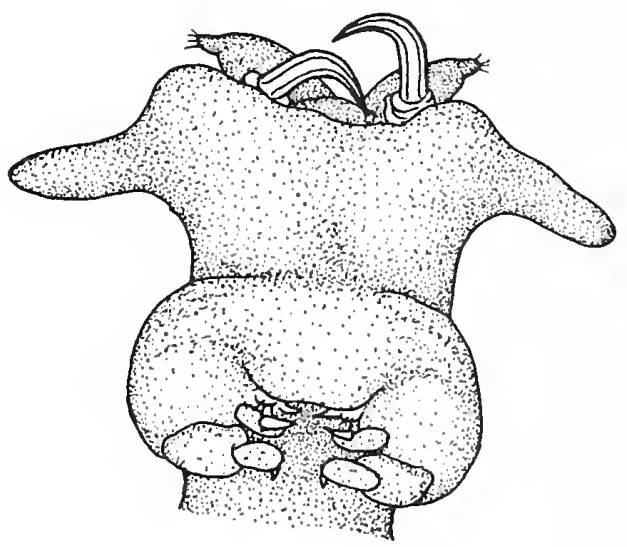

Figure 8.-Pseudochondracanthus diceraus; head, ventral view. 


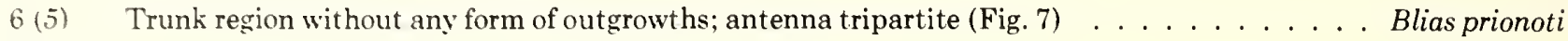

6 (5) Trunk region with outgrowths in form of processes, protrusions, or knobs; antennae uncinate (Fig. 8) $\quad \ldots \quad \ldots$

7 (6) Trunk region with only one pair of processes at the posterior end of the body (Fig. 1) $\ldots \ldots$

7 (6) Trunk region with more than one pair of processes $\ldots \ldots \ldots \ldots$

8 (7) One pair of lobate legs present; head bearing a pair of lateral processes (Fig. 8) _ . . . . . .

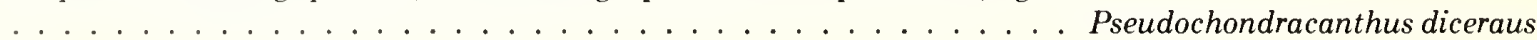

8 (7) Two pairs of lobate legs present; head without lateral processes $\ldots \ldots \ldots$

9 (8) Legs unilobate (Fig. 9); parasite of elasmobranchs ... Acanthochondrites annulatus

Figure 9.-Acanthochondrites annulatus; leg.

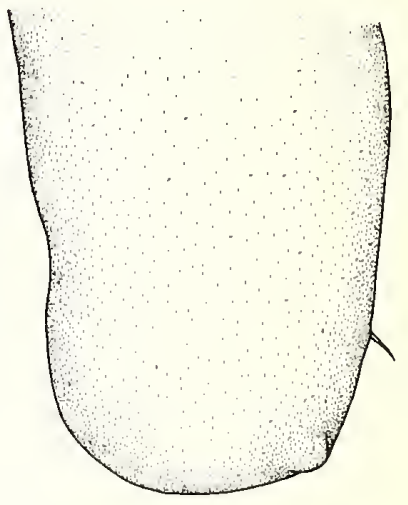

9 (8) Legs bilobate (Fig. 10); parasite of teleosts . . . . . . . . . 10

Figure 10.-Acanthochondria phycidis; leg.

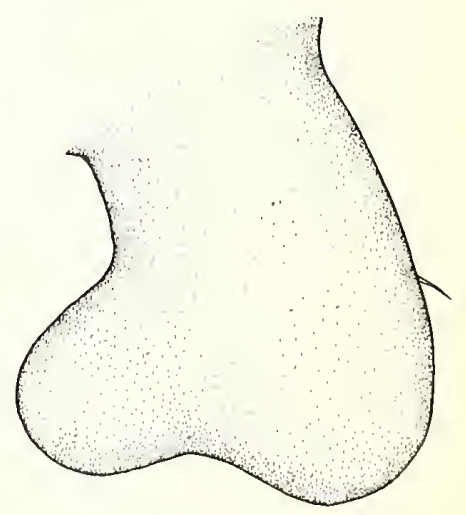




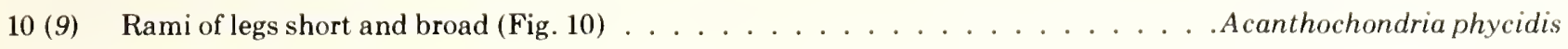

10 (9) Rami of legs long and conical (Fig. 11) . . . . . . . 11

Figure 11.-Acanthochondria galerita; leg.

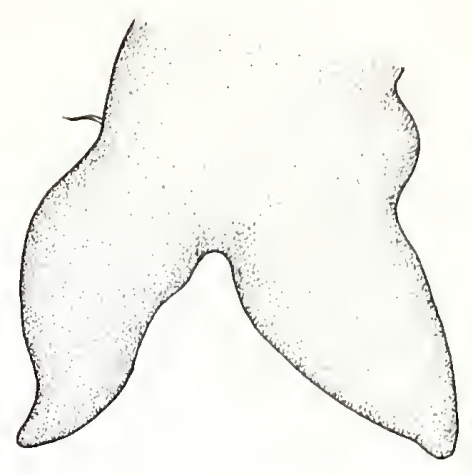

11 (10) Antennule small (relative to head) and filiform (Fig. 12) . . . . . . . Acanthochondria exilipes

Figure 12.-Acanthochondria exilipes; head.

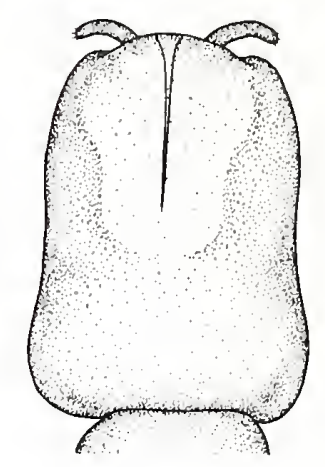

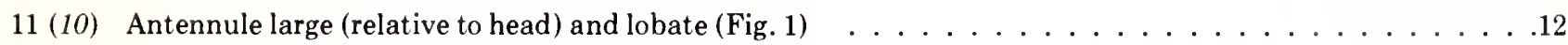

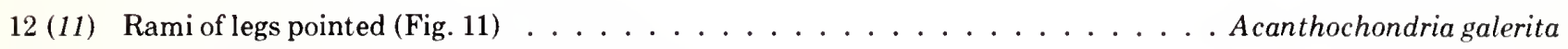

12 (11) Rami of legs not pointed (Fig. 13) . . . . . . .

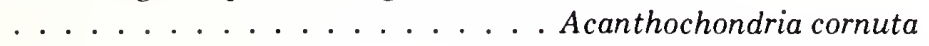

Figure 13.-Acanthochondria cornuta; leg.

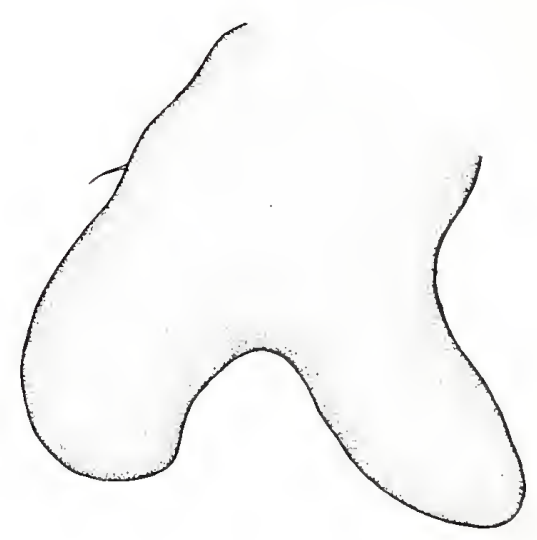




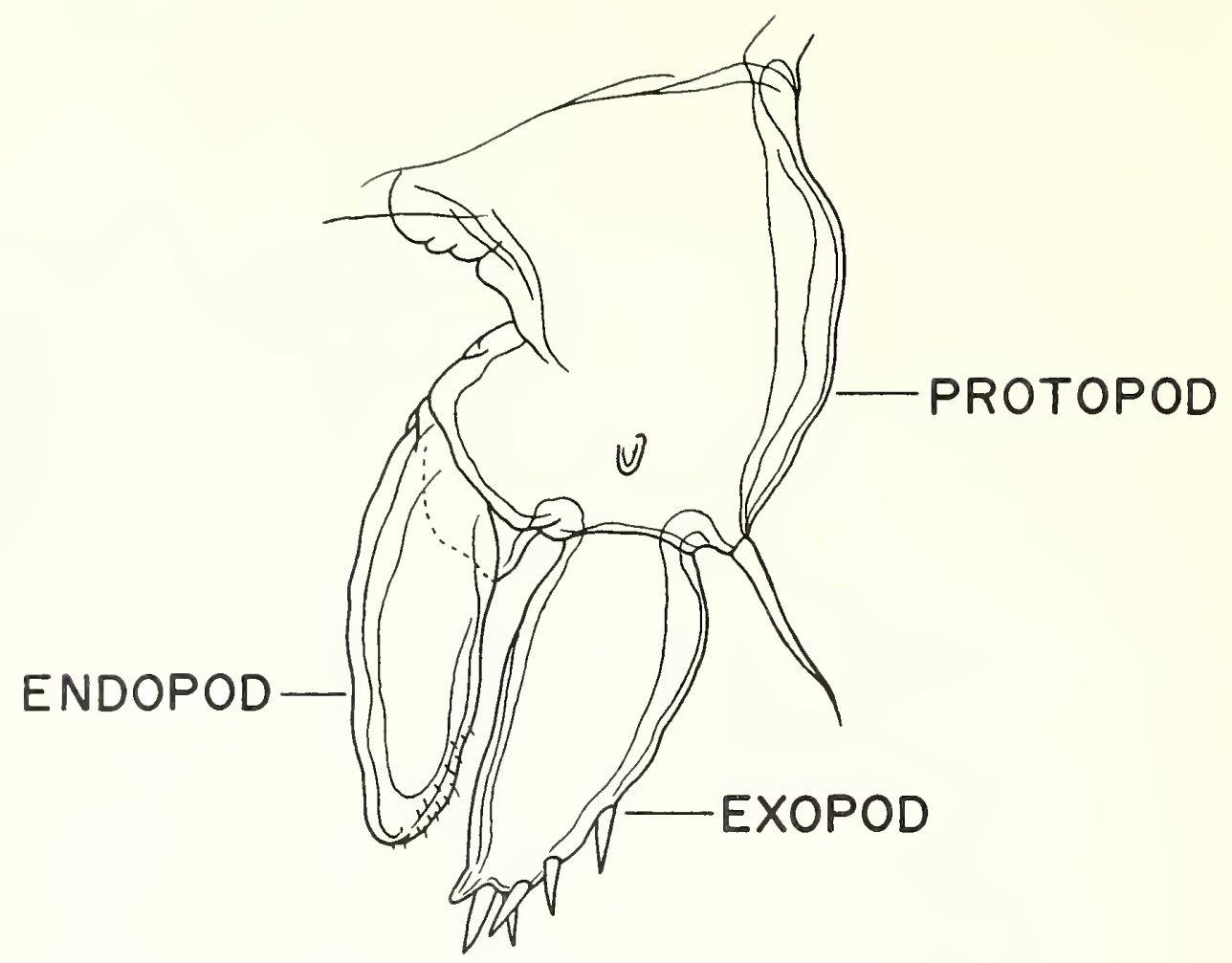

Figure 14.-Chondracanthodes deflexus; leg.

13 (7) Legs completely modified, either bilobate (Fig. 13) or trilobate (Fig. 15) . . . . . . . . . . . . . 14

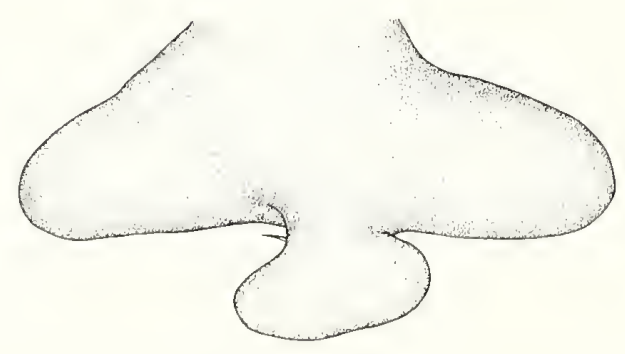

Figure 15.-Chondracanthus nodosus; leg. 
Figure 16.-Chondracanthus merluccii; head.

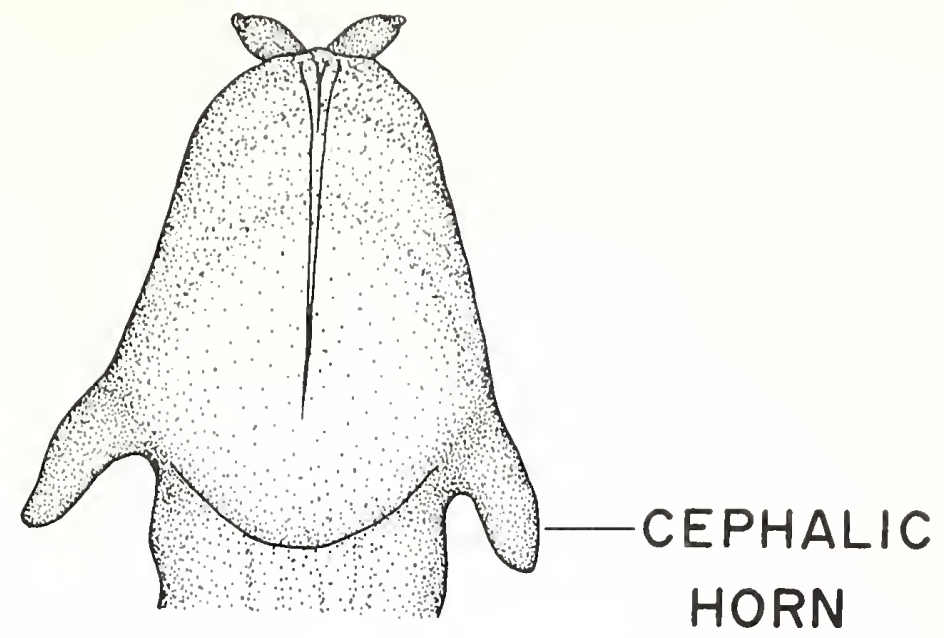

15 (14) Head without cephalic horns; antennule large (relative to head) (Fig. 17) . . . . Chondracanthus cottunculi

Figure 17.-Chondracanthus cottunculi; head.

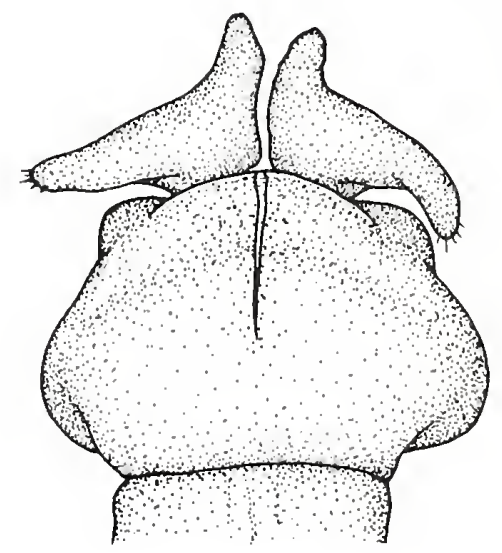

\section{ANNOTATED SYSTEMATIC LIST}

This list is arranged alphabetically in families, genera under their family, and species under their genus. Notes on host and distribution are given. When more than one host is known, their names are arranged alphabetically in genera and species under their genus. If the common name of the host is known, it is given immediately preceding its scientific name. Reference to important works are cited at the end of each species.

\section{Family BOMOLOCHIDAE}

Holobomolochus albidus (Wilson 1932). In gill cavity of angler, Lophius piscatorius, off Woods Hole, Mass. (Vervoort 1969).

Nothobomolochus teres (Wilson 1911). In gill cavity of Gulf menhaden, Brevoortia patronus, off Texas; Atlantic menhaden, B. tyrannus, from Massachusetts to
Florida; striped mullet, Mugil cephalus, off Texas (Pillai 1965).

Nothobomolochus saetiger (Wilson 1911). In gill cavity of tropical two wing flyingfish, Exocoetus volitans, off Woods Hole, Mass.; Cypselurus callopterus from Galápagos Islands (Wilson 1911).

\section{Family CHONDRACANTHIDAE}

Acanthochondria cornuta (Müller 1776). In gill and oral cavities of largescaled tonguesole, Cynoglossus macrolepidotus, off Ceylon; witch flounder, Glyptocephalus cynoglossus, in Massachusetts Bay and eastern North Atlantic; American plaice, Hippoglossoides platesoides, in North Sea, off Iceland and Greenland, and from Maine to Massachusetts; Atlantic halibut, Hippoglossus hippoglossus, off Midleton Island, Alaska; whiff, Lepidorhumbus whiffiagonis, in eastern North Atlantic; dab, Limanda limanda, in 
Irish Sea and off Iceland: flounder. Platichthys flesus, in North Sea: European plaice, Pleuronectes platessa, in eastern North Atlantic: Alaska, plaice, $P$. quadrituberculatus off Pallas. Alaska; turbot, Psetta maxima. off Sweden: winter flounder. Pseudopleuronectes americanus, from Maine to Massachusetts (Ho 1970).

Acanthochondria exilipes Wilson 1932. On gills of tilefish. Lopholatilus chameleonticeps, off Martha's Vineyard. Nantucket, and Woods Hole, Mass. (Ho 1970). Acanthochondria galerita (Rathbun 1886). In oral cavity of Gulf flounder, Paralichthys albigutta, off Florida. summer flounder, $P$. dentatus, off Woods Hole. Mass. (Ho 1971b).

Acanthochondria phycidis (Rathbun 1886). On gills of Chilean hake, Merluccius gayi, off Chile; spotted hake, Urophycis reguis, off Georgia and Florida; white hake, U. tenuis, off Martha's Vineyard, Mass.; unknown host from Falkland Islands (Ho 1971b).

Acanthochondrites annulatus (Olsson 1868). On gills of flapper skate, Raja batis, off Norway; spiny rasp skate, $R$. kenojei, in Sea of Japan; barndoor skate, $R$. laevis off South Harpswell, Maine (Ho 1970).

Blias prionoti Krøyer 1863. On gills of black drum, Pogonias cromis, off Mississippi; northern searobin, Prionotus carolinus, off North Carolina; soldier searobin, P. miles pectoralis, off Texas; leopard searobin, $P$. scitulus, off Florida; striped searobin, $P$. evolans, off Woods Hole, Mass.; bighead searobin, P. tribulus, off Florida (Ho 1970).

Chondracanthodes deflexus Wilson 1932. On gills of marlin-spike, Nezumia bairdi, off Woods Hole, Mass.; Macrurus sp. from Galápagos Islands; Coryphaenoides abyssorum off California (Ho 1970).

Chondracanthus cottunculi Rathbun 1886 . In gill cavity of arctic sculpin, Cottunculus microps, and pallid sculpin, C. thompsonii, off New England coast (Ho 1971b). Chondracanthus merluccii (Holten 1802). In oral and gill cavities of silver hake, Merluccius bilinearis, from Massachusetts to Florida; cape hake, $M$. capensis, off South Africa; European hake, M. merluccius, in eastern North Atlantic (Ho 1971b).

Chondracanthus nodosus (Müller 1776). In gill cavity of redfish, Sebastes marinus, in North Atlantic; deepwater rosefish, S. mentella, in eastern North Atlantic; Norway haddock, S. viviparus, in North Sea (Ho 1971b).

Pseudochondracanthus diceraus Wilson 1908. On gills of smooth puffer, Lagocephalus laevigatus, from Gulf of Mexico; northern puffer, Sphoeroides maculatus, from Massachusetts to North Carolina; southern puffer, S. nephelus, from Gulf of Mexico; bandtail puffer, S. spengleri, from North Carolina to Florida (Ho 1970).

\section{Family ERGASILIDAE}

Ergasilus labracis Krdyer 1863. On gill filament of striped bass, Morone saxatilis, from Massachusetts to Virginia (Roberts 1970).
Ergasilus manicatus Wilson 1911. On gill gilaments of sheepshead minnow, Cyprinodon variegatus, from Beaufort, N.C.; mummichog, Fundulus heteroclitus, from Cape Ann, Mass.; striped killifish, F. majalis, from Beaufort, N.C.; blackspotted stickleback, Gasterosteus wheatlandi, from Cape Ann, Mass.; rainwater killifish, Lucania parva, from Beaufort, N.C.; Atlantic silverside, Menidia menidia, from Woods Hole, Cape Ann, and Barnstable, Mass.; rainbow smelt, Osmerus mordax, from St. Andrews, New Brunswick (Roberts 1970).

\section{Family PHILICHTHYIDAE}

Philichthys xiphiae Steenstrup 1861. In cephalic canals of swordfish, Xiphias gladius, in Mediterranean, off European and American coasts off North Atlantic, New Zealand, and Japan (Delamare-Duboutteville 1962).

\section{Family TAENIACANTHIDAE}

Anchistrotos occidentalis Wilson 1924. On gills of striped burrfish, Chilomycterus schoepfi, from Woods Hole, Mass. (Humes and Rosenfield 1960).

\section{Family TUCCIDAE}

Tucca impressus Krbyer 1837. On fins of bridled burrfish, Chilomycterus antennatus, from Jamaica; striped burfish, C. schoepfi, from Massachusetts to Louisiana; porcupinefish, Diodon hystrix, from Jamaica; northern puffer, Sphoeroides maculatus, from Woods Hole, Mass.; spinyback puffer, S. marmoratus, from Jamaica (Ho 1967a).

\section{LITERATURE CITED}

CRESSEY, R. F.

1975. A new family of parasitic copepods (Cyclopoida, Shiinoidae). Crustaceana 28:211-219.

DELAMARE-DEBOUTTEVILLE, C.

1962. Prodrome d'une faune d'Europe des copépodes parasites de poissons. Les copépodes Philichthyidae. Bull. Inst. Océanogr. Monaco 57:1-44.

HO, J.-S

1967a. Cyclopoid copepods of the genus Tucca (Tuccidae), parasitic on diodontid and tetraodontid fishes. U.S. Fish Wildl. Serv., Fish. Bull. 66:285-298.

1967b. Cyclopoid copepods of the genus Telson parasitic on uranoscopid fishes in the Gulf of Mexico. J. Parasitol. 53:852-858.

1970. Revision of the genera of the Chondracanthidae, a copepod family parasitic on marine fishes. Beaufortia 17:105-218.

1971a. Pharodes Wilson, 1935, genus of cyclopoid copepods (Pharodidae) parasitic on marine fishes. J. Nat. Hist. 5:349-359.

1971b. Parasitic copepods of the family Chondracanthidae from fishes of eastern North America. Smithonian Contrib. Zool., no. $87,39 \mathrm{p}$.

HUMES, A. G., and D. C. ROSENFIELD.

1960. Anchistrotos occidentalis C. B. Wilson, 1924 (Crustacea, Copepoda), a parasite of the orange filefish. Crustaceana 1:179187.

IZAWA, K.

1973. On the development of parasitic copepoda. I. Sarcotaces 
pacificus Komai (Cyclopoida: Philichthyidae). Publ. Seto Mar. Biol. Lab. 21:77-86.

PILLAI, N. K.

1965. Redescription of seven species of bomolochids from the collections of the United States National Museum. J. Mar. Biol. Assoc. India, 7:243-269.

ROBERTS, L. S.

1970. Ergasilus (Copepoda: Cyclopoida): Revision and key to species in North America. Trans. Am. Microsc. Soc. 89:134-161.

SPROSTON, N. G., W. Y. YIN, and Y. T. HU.

1950. The genus Lamproglena (Copepoda Parasitica), the discovery of the life-histories and males of two Chinese species from food fishes, revealing their relationship with Lernaea and of both to the Cyclopoidea. Sinensia, New Ser. 1:51-8.4

VERVOORT, W.

1969. Caribbean Bomolochidae (Copepoda: Cyclopoida). Stud. Fauna Curaçao and other Caribb). Is. 28:1-125.

WILSON, C. B

1911. North American parasitic copepods belonging to the family Ergasilidae. Proc. U.S. Natl. Mus. 39:263-400.

YAMAGUTI, S.

1963. Parasitic Copepoda and Branchiura of fishes. Interscience Publ., New York, London, Sydney, 1104 p.

\section{SYSTEMATIC INDEX}

\section{Acanthochondria}

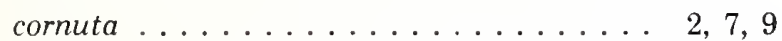

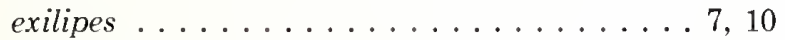

galerita .................. 7,10

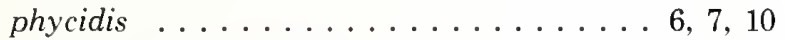

Acanthochondrites annulatus ....... 6, 10

Anchistrotos occidentalis ........ 4, 10

Blias prionoti ............ 5, 6, 10

Bomolochidae ............. 1, 3, 4, 9

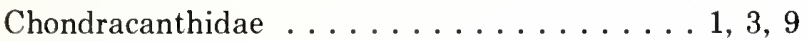

Chondracanthodes deflexus . . . . . . . . 8, 10

Chondracanthus

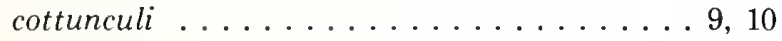

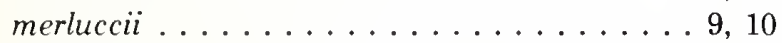

nodosus ................. 8, 10

Ergasilidae ............... 3, 4, 10

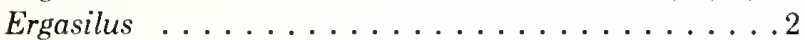

labracis ................. 4, 10

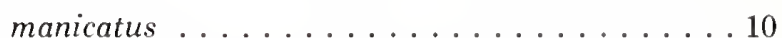

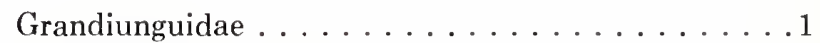

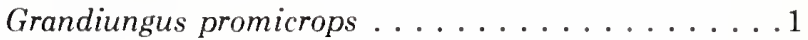

Holobomolochus albidus ............ 3, 9

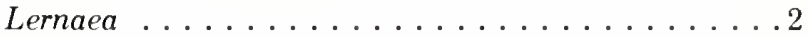

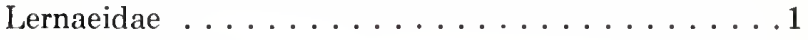

Nothobomolochus

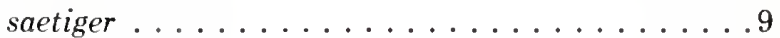

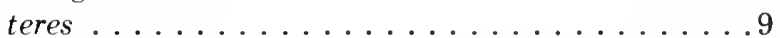

Philichthyidae ........... 1, 3, 10

Philichthys xiphiae ........... 5, 10

Pseudochondracanthus diceraus ...... 5, 6, 10

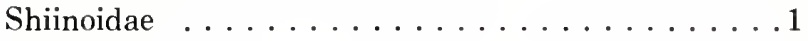

Taeniacanthidae ............ 3, 4, 10

Telsidae ..................... . . .

Tucca impressus ............ 4, 5, 10

Tuccidae .............. 1, 3, 10 


\section{ACKNOWLEDGMENTS}

Preparation of the "Marine Flora and Fauna of the Northeastern Inited States" is being coordinated by the following Boord:

Cordinating Editor: Melbourne R. Carriker, College of Marine Studies. University of Delaware, Lewes, DE 19958.

Editorial Advisers:

Marie B. Abbott, Marine Biological Laboratory, Woods Hole. Mass.

Arthur G. Humes, Boston University Marine Program, Marine Biological Laboratory, Woods Hole, Mass.

Mesley N. Tiffney. Department of Biology, Boston University, Boston, Mass.

Ruth D. Turner. Museum of Comparative Zoology, Harvard University, Cambridge, Mass.
Roland L. Wigley, National Fisheries Services Northeast Fisheries Center, NOAA, Woods Hole, Mass.

Robert T. Wilce, Department of Botany, University of Massachusetts, Amherst, Mass.

The Board, which established the format for the "Marine Flora and Fauna of the Northeastern United States," invites systematists to collaborate in the preparation of manuals, reviews manuscripts, and advises the Scientific Editor of the National Marine Fisheries Service.

All illustrations were made from the collections in the Division of Crustacea, National Museum of Natural History, Smithsonion Institution, Washington, D.C. Melbourne R. Carriker, Bruce C. Coull, Roger F. Cressey, and Arthur G. Humes critically read the manuscript.

\section{COORDINATING EDITOR'S COMMENTS}

Publication of the "Marine Flora and Fauna of the Northeastern United States" is most timely in view of the growing universal emphasis on environmental work and the urgent need for more precise and complete identification of coastal organisms than has been available. It is mandatory, wherever possible, that organisms be identified accurately to species. Accurate scientific names unlock the great quantities of biological information stcred in libraries, obviate duplication of research already done. and often make possible prediction of attributes of organisms that have been inadequately studied.

Ju-shey Ho began his study of the systematics of the parasitic Copepoda in 1960 when he was a teaching assistant at the Department of Zoology, National Taiwan University, Taipei, Taiwan. In 1962 he went to Boston University to pursue graduate studies on the copepod parasites of marine animals. Ho joined the faculty of California State University, Long Beach, in 1970 where he has continued his research on parasitic
Copepoda. His studies have resulted in more than 50 papers on the systematics of marine parasitic copepods, including a monographic revision of Chondracanthidae at the generic level. Currently he is working on a series of copepod parasites from the fishes of the Great Barrier Reef, Australia.

Preparation of this manual was supported in part by' a grant from the Environmental Protection Agency to the Editorial Board of the "Marine Flora and Fauna of the Northeastern United States." Work on the "Marine Flora and Fauna of the Northeastern United States" by the Coordinating Editor is supported by the College of Marine Studies, University of Delaware.

Manuals are available for purchase from the Superintendent of Documents, U.S. Government Printing Office, Washington, DC 20402. The manuals so far published in the series are listed below:

\section{Marine Flora and Fauna of the Northeastern United States}

COOK. DAVID G., and RALPH O. BRINKHURST. Annelida: Oligochaeta. 374

BORROR. ARTHUR C. Protozoa: Ciliophora. 378

MOLL. EDWTN T. Higher Plants of the Marine Fringe. 384

McCLOSKEY, LAWRENCE R. Pycnogonida. 386

MANNING, RAYMOND B. Crustacea: Stomatopoda. 387

WILLIAMS, AUSTIN B. Crustacea: Decapoda. 389

POLLOCK, LELAND W. Tardigrada. 394

LARSON, RONALD J. Cnidaria: Scyphozoa. 397

CAVALIERE, A. R. Higher Fungi Ascomycetes, Deuteromycetes, and Basidiomycetes. 398

COLLL, BRUCE C. Copepoda: Harpacticoida. 399

CLTLER, EDWARD B. Sipuncula. 403

PAWSON, DAVID L. Edhinodermata: Holothuroidea. 405

HO, JU-SHEY. Copepoda: Lernaeopodidae and Sphyriidae 406

HO, JU-SHEY. Copepoda: Cyclopoids Parasitic on Fishes 409 
388. Proceedings of the first U.S. Japan moeting on aquaculture at Tokyo, Japan, October 18-19, 1971. William N. Shaw (editor). (18 papers, 14 authors.) February 1974, iii +1333 p. For sale by the superintendent of Documents, Ls. Government Printing Office, Washington, I) ('. 2040)

389. Marine tlora and fauna of the northeastern Inited states Crustacea: Decapuda. Bv Austin B. W'illiams. ApriI 1974, iii + 50 p., 11 figs. For sale by the superintendent of Documents, U.S. Govermment Printing Office. Washington, D.C. 20.402

390. Fishery pullications, calendar yar 197:3: Lists and indexes. By Mary Eillen Engett and Lee $C$. Thorson. September 1974 , iv +14 p.. 1 fig For sale by the Superintendent of I)ocuments. I.S. Government Printing Otfice, Washington, D.C. '20402.

391. Calanoid copepods of the genera Spinocalanus and Mimocalanus from the central Arctic Ocean, with a review of the Spinocalanidae. By David M. Damkaer. June 1975, $\mathrm{x}+88$ p., 225 figs. 4 tables. For sale by the superintendent of Documents, U.S. Government P'rinting office, Washinguon, D). 2.20402 .

392. Fislucry publications, colendar year 1974: 1,ists and indexes. By Lee (Chorson and Mary Ellen Fingett. June 1975, iv + 27 p.. 1 tigg

39:3. Conperative Gulf of Mexicoestuarine inventory and study- Texas: Area description. By Richard A. Diener. September 1975, vi + 129 p. 5.5 tigs. 26 tahles.

39.4. Marine Flora and Fanna of the Northeastern United States. Tar

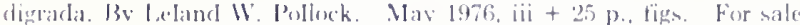

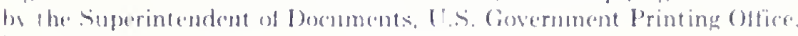

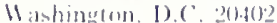

395. Report of a colloguium on larval fish mortality studies and their relation 10 tishery research, January 1975. By John R. Hunter. May 1976 , iii +5 p. For sale by the Superintendent of Documents, Is Goremment Printing Office. Washington, 1).C. 20402. 


\section{NOAA SCIENTIFIC AND TECHNICAL PUBLICATIONS}

NOAA, the National Oceanic and Atmospheric Administration, was established as part of the Department of Commerce on October 3, 1970. The mission responsibilities of NOAA are to monitor and predict the state of the solid Earth, the oceans and their living resources, the atmosphere, and the space environment of the Earth, and to assess the socioeconomic impact of natural and technological changes in the environment.

The six Major Line Components of NOAA regularly produce various types of scientific and technical information in the following kinds of publications:

PROFESSIONAL PAPERS-Important definitive research results, major techniques, and special investigations.

TECHNICAL REPORTS-Journal quality with extensive details, mathematical developments, or data listings.

TECHNICAL MEMORANDUMS-Reports of preliminary, partial, or negative research or technology results, interim instructions, and the like.

CONTRACT AND GRANT REPORTS-Reports prepared by contractors or grantees under NOAA sponsolship.
TECHNICAL SERVICE PUBLICATIONSThese are publications containing data, observations, instructions, etc. A partial listing: Data serials; Prediction and outlook periodicals; Technical manuals, training papers, planning reports, and information serials; and Miscellaneous technical publications.

ATLAS-Analysed data generally presented in the form of maps showing distribution of rainfall, chemical and physical conditions of oceans and atmosphere, distribution of fishes and marine mammals, ionospheric conditions, etc.

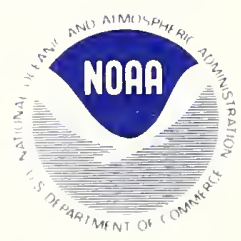

Information on avallablilty of NOAA publlcations can be obtalned from:

ENVIRONMENTAL SCIENCE INFORMATION CENTER ENVIRONMENTAL DATA SERVICE NATIONAL OCEANIC AND ATMOSPHERIC ADMINISTRATION U.S. DEPARTMENT OF COMMERCE 